\title{
TOURISM ECONOMY. MOUNTAIN TOURISM: QUANTITATIVE ANALYSIS OF WINTER DESTINATIONS IN ROMANIA
}

\author{
Ioan-Bogdan BACOȘ ${ }^{1}$, Manuela Rozalia GABOR ${ }^{2}$
}

date of paper receipt:

28.12.2020.

Original Article date of sending to review:

31.12.2020.

doi: 10.2478/eoik-2021-0005 date of review receipt:

15.01.2021.

UDK 338.486.1.02-44(23.0)(498)

1,2 "George Emil Palade" University of Medicine, Pharmacy, Sciences and Technology of Târgu Mureș, Street Gh. Marinescu nr 38, Târgu Mureș, 540290, România, e-mail: manuela.gabor@umfst.ro

\begin{abstract}
The continuous development of mountain tourism derives from the multiple positive points that the mountain has in satisfying the particularly diverse tourist needs. The strong point is represented by the extremely valuable and complex tourist potential, as well as the variety of natural and anthropic resources. The complementarity of these resources makes the arrangement and development of winter resorts with a useful and attractive profile called ski areas to be more and more common in mountainous areas. The purpose of this paper is to analyze winter destinations in order to conclude whether Romania can create a competitive advantage based on this type of tourism, both at European and global level. We used statistical data for all Romanian resort for sky destination, respectively the total number of practicable kilometers, total number of cableway installations and the accommodation capacity. For the quantitative analysis we used the SPSS 23.0 statistical software and applied the following statistical methods: Person correlations, chi square test and Student's $t$ test for paired samples. The research results, obtained with statistical methodology, support and highlight the significant differences between the Romanian mountain resorts for winter activities.
\end{abstract}

\section{Keywords:}

mountain tourism, winter tourism, winter sports, winter destinations, quantitative analysis, Romania 


\section{INTRODUCTION}

The mountain attracts the most important flows of tourists and it is becoming an important factor for the population both socially and educationally through its recreational, disconnecting, healing and sports capabilities. Mountain tourism is on the second place of the Romanian tourist in the last two years, before the COVID 19 pandemic time (Baba et al., 2020). It is known that Romania has rich natural resources (Nagy, 2019) that can support winter tourism activities. Also, since 2007, Romania has access to financial resources that can be directed to the development of such winter destinations, the long-term consequence being that of the sustainability of those areas and especially the development of local mountain economies. According to the European Commision study Mountain Areas in Europe „Europe's mountains are of vital importance to the continent's population in four main ways, including or providing opportunities for recreation and tourism, based on natural attributes and cultural heritage (Coca \& Blaga, 2020)

From the latest report of the Swiss specialist L. Vanant (International Report on Snow and Mountain Tourism, 2020) it can be deduced that European resorts receive more visitors in general than those in North America (The Ski Guru, 2020) and Romania is not found in the top destinations in this report. The main countries recognized as inbound ski destinations are according to this report (International Report on Snow and Mountain Tourism, 2020, p. 19): Austria, Switzerland, Italy and France. The main countries that send tourists to outbound ski destinations are the United Kingdom, Germany, the Netherlands, Belgium, and Switzerland. European external markets are not growing but will be expanded to more destinations in the future. For example, British customers familiar with the Alps and Andorra now have other destinations to choose from, such as Bulgaria, Romania, Slovakia, etc. It is also foreseeable that new markets will be supplied at regional level (International Report on Snow and Mountain Tourism, 2020, p. 19).

According to the same report (International Report on Snow and Mountain Tourism, 2020, p.128) the Carpathian Mountains are the second largest mountain range in Europe, but Romania is still quite an unknown and undiscovered winter vacation destination. It has 44 ski resorts with about 150 ski lifts, $20 \%$ of which have been installed or renewed in the last 15 years. It is an attractive destination for foreign visitors, as the prices are relatively low compared to most of Europe, and some ski slopes are lit for night skiing. However, overpasses are not considered cheap due to limited infrastructure and poor care. It is estimated that ski resorts in Romania will attract approximately 1.2 million visits to skiers per year.

Developed by a team of experts from the World Tourism Organization together with Romanian counterparts on behalf of the Romanian Government, the Master Plan for National Tourism Development 2007 - 2026 it is the main engine for the implementation of the ministry's tourism policies. The role of the National Organization for Tourism is the same as for encouraging and promoting the development of tourism to and within Romania. The objectives of the Master Plan are based in particular on the identification of key points in the Romanian tourism industry in order to develop strategies aimed at transforming them into strengths through existing opportunities and huge market demands. The sustainable development of the tourism industry, with the conservation of natural and anthropic resources is the vision of the master plan. Accroding to Gabor et al. (2012) and Gabor \& oltean (2017) the low level of Romanian tourism ompetitiveness, it can be explained by consistent measures as tourism is a widely complex system of interdependencies and correlations.

Sustainable development is a dynamic concept, with many dimensions and interpretations, seen as a process of permanent change, very connected to the national and local context, national and local needs, and priorities. The foundations of sustainable development refer to the use of resources 
in a sustainable way, use that must meet human needs in accordance with the preservation of the environment, the rational use of economic resources in a socio-political framework appropriate to the needs. Global code of ethics for tourism adopted in 2001 by UMWTO is a resolution that can be considered as a basis of Sustainable Tourism. There are several articles that directly refers to the two main keys of cultural and eco-tourism: tourism contribution to the mutual understanding and respect between peoples and societies and tourism as a factor of sustainable development. Also, regarding the importance of sustainability, especially for Carpathians countries, Coca \& Blaga (2020) point out that there are significant correlations between environmental performance and GDP/unit of energy use and between ISO14001 environmental certificates/bn PPP\$ GDP and Gross capital formation, \%GDP.

The Brundland Commission defines sustainable development as "meeting current needs without compromising the chances of future generations to meet their own needs". A major consequence of sustainable development for both current and future generations is an increase in the quality of life. Conceptually, sustainable development results from the reunion of the 3 major areas: environmental sustainability, rational sustainability of the social / political environment and sustainable development of the environment. All mountain tourist activities have an ecological footprint on the environment. Activities such as travel, accommodation, the creation of travel packages and food consumption can have a negative effect and impact if not managed properly. However, mountain tourism has several benefits from environmental sustainability, such as: the involvement of administrative agencies in the conservation of natural resources, the creation of economic value, regional development, and the protection of cultural and environmental heritage.

Winter Tourism is concentrated in areas of high natural value, such as national parks, coastal areas and mountainous regions that support rich or unique biodiversity. The Convention on Biological Diversity (CBD) defines biodiversity as "the variety of genes, species and ecosystems (marine, terrestrial, inter alia and other aquatic systems) that constitute life on earth. Also in the area of biodiversity are included the different ecological complexes with differentials and the diversity between and between species.

Sustainable environment management is a systematic approach to identifying practical ways to save water, energy, material resources and reduce the negative impact on the environment. A proactive environment program proposes a management perception with three main directions. These directions can help a property / country save money, be recognized for environmental protection, and preserve natural resources or unique tourist destinations for future consumers.

- Saving financial resources - environmental management reduces operating costs and improves profitability. Most hotels can quickly achieve substantial costs or savings with a modest investment in simple low-cost technologies to achieve an annual return on investment of $100 \%$.

- Public recognition for involvement in environmental protection - the adoption of best environmental practices can help a hotel stand out from the competition by being recognized through various certification programs, awards, tour operator programs and other special promotions. Being recognized for its involvement in environmental management can improve the image of the property, an image created by both environmentally conscious and passionate tourists and tourism operators.

- $\quad$ Protecting and preserving tourist destinations and natural resources - every year millions of tourists choose to practice tourism with the main goal of relaxing and experiencing natural resources, cultural treasures or natural treatment in different regions or tourist destinations. The tourism industry, while being a critical engine for so-called economic growth, also puts tremendous pressure on "goods" or natural resources such as beaches, reefs, rivers, forests, air, land, stones and archaeological remains, etc. 
Climate change could be a alter within the collective design of expression of climate components over time. The current situation which is checked by worldwide warming is of concern for three fundamental reasons:

- Temperatures are rising more quickly than they have done for 10,000 years.

- A solid relationship between current worldwide warming and increments within the climatic concentration of greenhouse gasses;

- Irresponsible investment in all industries consuming natural resources.

Sustainable investment in the tourism industry offers additional protection to natural resources, essential for the most tourism activities. Their irresponsible use and the continuous degradation of the environment, lead to major climate change, thus interrupting the transfer of resources to future generations.

The purpose of this paper is to analyze winter destinations to conclude whether Romania can create a competitive advantage based on this type and sustainable tourism both at European and global level. This paper addresses issues regarding mountain tourism, winter destinations and the dynamics of winter sports in Romania. At the same time, the paper contains a short description of winter destinations in Romania, the capacity and number of accommodation places and the annual trends according to the National Institute of Statistics of Romania. This paper fills a gap in the literature, both of theoretical and practical pint of view, being the first that use the statistical analysis for winter destinations in Romania.

\section{WINTER AND SPORTS TOURISM - BACKGROUND AND CONCEPTUAL FRAMEWORK}

Winter tourism has been defined as the coldest season of the year, between autumn and spring, astronomically, from the December solstice to the March equinox in the northern hemisphere, and at the opposite pole of the year in the southern hemisphere. Tourism has become a desirable leisure activity worldwide. It can be both domestic and international, with implications for both revenue and output on a country's balance of payments. Today, tourism is a major source of income for many countries and it affects the economy of both the source country and the host country, which can be of vital importance in some cases.

Mountain tourism correlated to winter sports, is a form of sports tourism developed both in winter and in spring-autumn (figure skating), and it is closely linked to other activities held in mountain resorts, as it is practically related to these resorts. In order to stimulate the practice of winter sports, it is necessary to invest in a technical infrastructure, consisting of: means of transport (cable in general) and specially designed slopes. Winter sports developed rapidly because of people's desire to spend their free time doing recreational activities or relaxation activities, and the desire to exercise. The dimensions of tourism for winter sports can be limited by the restrictive period in which they can be practiced, at the same time, an important factor in the good development of this sport is the favorable natural snow layer, as well as thickness, persistence and even stability.

\subsection{WINTER SPORTS CLASSIFICATION}

Winter sports are sports that are practiced in the cold winter season. The most popular winter sports are those practiced with the help of skis: Alpine skiing, freeride skiing, freestyle skiing, offpiste skiing, ski jumping, etc. A basic classification of the main winter sports, according to the Olympic Games, is found in figure no. 1. 
Figure 1. The main winter sports
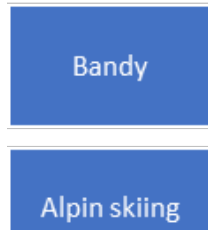

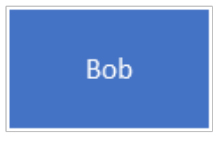

Sketlon
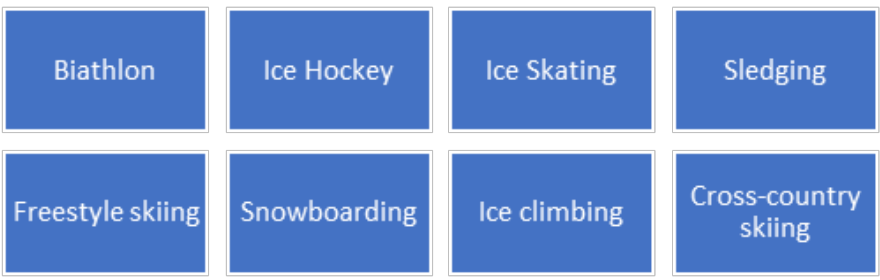

Source: Realized by the author based on the information from https://www.topendsports.com.html

In addition to the classic classifications, extreme winter sports should also be mentioned. According to Trip.com, 10 of the most extreme new winter sports, which appeared after 2010 are: Snow kiting, Ice yachting, snow kayaking, Ice diving, Snow-cross, Speed flying, Ski jumping, Big mountain skiing, Ice hockey, Snowboarding, Snowmobiling, Heli-skiing, Dog sledding, Ice climbing.

Competitiveness is inseparably connected to the idea of competition, communicating, generally, the capacity of people, companies, economies, or districts to preserve themselves within the neighborhood or worldwide competition and to advantage from it. Competitiveness means efficiency, seen as included esteem. It includes an energetic character, driving destinations to deliver up idleness and cultivate development. According to Ritchie \& Crouch competitiveness model (2003) Romania has many difficulties in managing and increase the winter destination competitiveness, including almost all the supporting factors and resources. If we take into consideration the Dwyer \& Kim competitiveness model (2009) we find other weaknesses: the lack of government involvement in created resources like winter destination infrastructure for skiing for example. The last affirmation is sustaining also by the Coca \& Blaga (2020) research results regarding the innovations in Carpathians countries.

\subsection{THE TOURIST POTENTIAL OF WINTER DESTINATION IN ROMANIA}

The value of Romania's tourist potential, characterized by the variety and harmony of landforms, the diversity of natural and anthropic tourist attractions, as well as the existence of unique resources, places Romania among the most favored countries, with opportunities to practice a "total tourism". Its enhancement involves the design of original and attractive tourism programs, on the most varied interests, specific to different areas of the country. The arrangement for tourism of the mountain area appeared in Romania at the end of the 19th century, when in Sinaia, the first mountain tourist association and society was established (Trinitatea Vremelnica, 1896, and Societatea Carpatina Sinaia 189330). In the interwar period, also in Sinaia, the first mountain resort was developed, followed by Busteni, Red Lake, Predeal and Cheia. Only after a few years will there be resorts for relaxation, recreation, mountain hiking and winter sports in Poiana Brașov, Borșa, Semenic, Stâna de Vale, Vidra, Voineasa, Durău, Azuga.

\subsection{CARPATHIANS MOUNTAINS - A SHORT DESCRIPTION}

The Carpathian Mountains rank 2nd in Europe for their size. It dominates the center of Romania, with 14 peaks reaching over 2000 meters altitude. Peaking 2544 meters above sea level, Moldoveanu Peak is the highest point. The winter season is dominant between November and April with a thick layer of snow until the end of March or even April. The ski resorts have a decent infrastructure, and the hotels are comfortable, offering various packages. The only disadvantage of this area is the relatively difficult accessibility in the famous winter destinations.

The complexity and attractiveness of the tourist potential of the Romanian Carpathians can be materialized in the organization of specific tourist programs: 
- excursions, hikes, routes and tourist itineraries on mountain routes, marked, in the Bucegi Mountains, Făgăraș, Retezat, Parâng, Ceahlău, Candel, Piatra Craiului, Postăvarul, Harghita:

- mountaineering in the Bucegi mountains, Piatra Craiului, Retezat.

- tourist orientation actions.

- speotourism in the Apuseni Mountains, Bucegi Mountains, Cerna Mountains, Mehedinți Mountains

- stays of 6-12 days for the practice of winter sports, for rest and treatment, or for the weekend on the occasion of various holidays.

- rural tourism in various mountain areas.

A development on a comparative scale for Romania, is found in the Montana Bucegi region, Barsei Mountains. The concentration of mechanical means on the cable and the length of the slopes represents $60 \%$ of the total ski area found in Romania. Tourists are generally attracted to: Sinaia, Busteni, Predeal, Poiana Brasov. Favorable conditions and the continuous development of other mountainous areas, brought a plus for the development of winter resorts in other areas such as: Mogoșa, Borșa, Vatra Dornei, Piatra Fântânele, Durău, Sovata, Bâlea Lac, Păltiniș, Rânca, Straja, Muntele Mic, Semenic, Arieșeni, Băișoara, Stâna de Vale, etc.

In Romania, there are currently 211 kilometers of slopes served by approximately 150 cable transport installations. In the list of the best ski resorts in Romania are the ski resorts Straja and Sinaia with 3 stars out of 5 stars according to the 2020 Report made by the Austrian website Skiresorts.info. Thus, Straja is also the largest ski resort offering the longest slopes (approximately $20 \mathrm{~km}$ ). The highest ski resorts in Romania stretch to an altitude of 2,208 meters (Balea Lac). A quantitative analysis of the main winter tourist destinations, respectively the number of kilometers of practicable winter sports areas, the total number of cable transport facilities, the accommodation capacity per county, and the number of cable transport facilities can be found in the Table no. 1.

Table 1. Accommodation capacity, number of resorts, total number of $\mathrm{km}$ and number of cable transport installations by counties

\begin{tabular}{|c|c|c|c|c|}
\hline County & No. of resorts & $\begin{array}{l}\text { Total no. of } \\
\text { practicable } \mathrm{km}\end{array}$ & $\begin{array}{l}\text { Total no. of cableway } \\
\text { installations }\end{array}$ & $\begin{array}{l}\text { Accommodation } \\
\text { capacity (2017) }\end{array}$ \\
\hline Alba & 1 & 12.3 & 3 & 191 \\
\hline Bacău & 1 & 1.4 & 1 & 147 \\
\hline Bihor & 3 & 4.2 & 5 & 216 \\
\hline Bistrița-Năsăud & 2 & 2.5 & 2 & 87 \\
\hline Brașov & 3 & 24.1 & 14 & 955 \\
\hline Caraș-Severin & 3 & 14 & 8 & 241 \\
\hline Cluj & 4 & 6.8 & 6 & 283 \\
\hline Covasna & 1 & 0.8 & 2 & 104 \\
\hline Gorj & 1 & 3.4 & 6 & 102 \\
\hline Harghita & 9 & 22.7 & 19 & 409 \\
\hline Hunedoara & 2 & 27.7 & 20 & 217 \\
\hline Iași & 1 & 0.5 & 1 & 85 \\
\hline Maramureș & 7 & 20.8 & 14 & 277 \\
\hline Mureș & 1 & 1.5 & 3 & 362 \\
\hline Neamț & 1 & 1.2 & 3 & 267 \\
\hline Prahova & 3 & 28.8 & 17 & 347 \\
\hline Sibiu & 3 & 18.2 & 8 & 338 \\
\hline Suceava & 3 & 11.2 & 7 & 441 \\
\hline Vâlcea & 1 & 6.1 & 5 & 260 \\
\hline
\end{tabular}

Source: Made by the author based on the information from https://www.skiresort.info/ski-resorts/romania/ 
From the data analysis and the graphical representation in figure no 2., a rational decrease of the number of transport installations at the same time with the decrease of the number of practicable kilometers can be observed. Straja, Sinaia and Poiana Brașov are on the first positions in the created rankings, with an average of 10 cable transport installations.

Figure 2. Graphical representation of the practicable distance and the number of transport installations

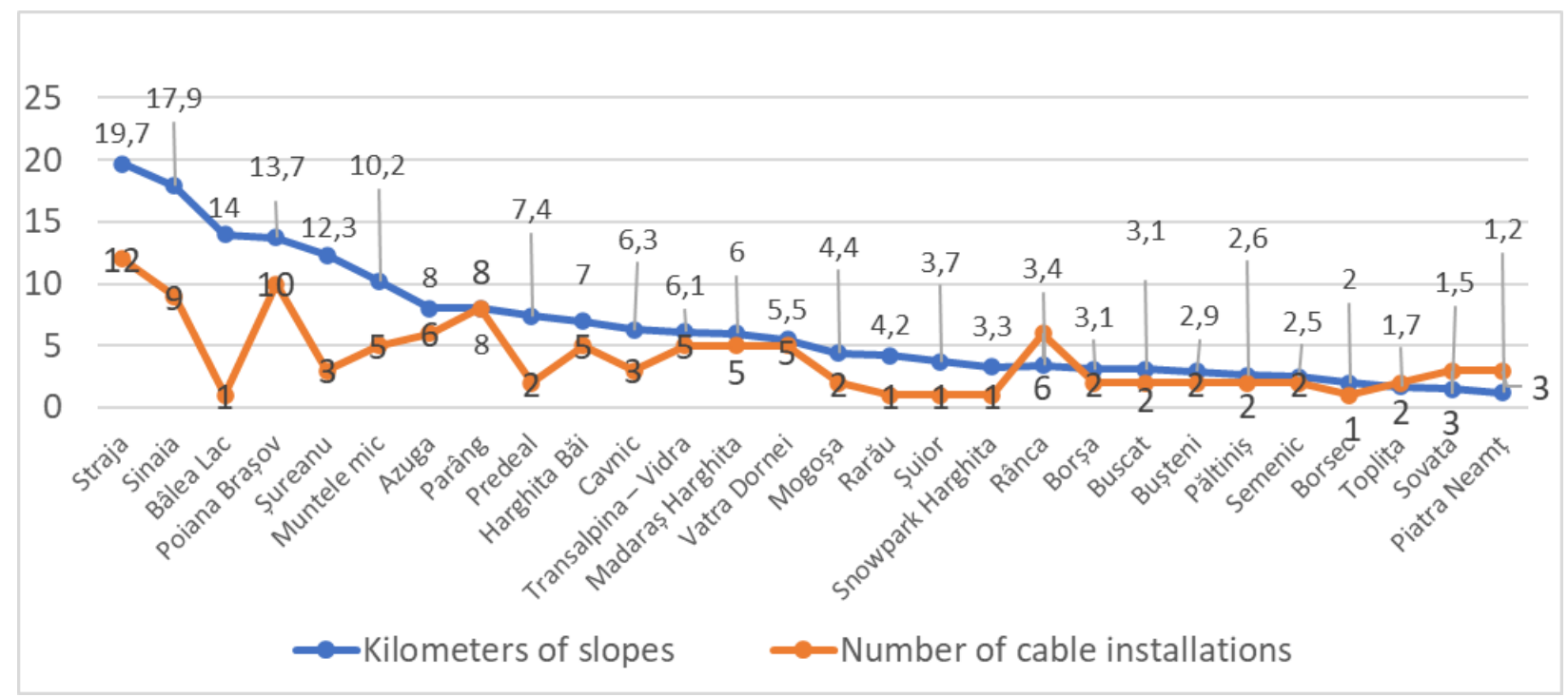

Source: Made by the author based on the information from table 1

The longest slope, namely the Straja slope from the Straja resort, with a length of 8,100 m declared to be the longest only in 2018, followed by the Drumul Roșu slope from Poiana Brașov, with a length of 5,500 $\mathrm{m}$ is in the top of the most used slopes by intermediate and advanced winter sports practitioners. There are also unarranged ski slopes such as the ski slopes on Transfăgărășan and Bâlea Lac. Here is the longest semi-arranged slope, practiced by free-ride ski lovers, namely the Black Slope with an advanced degree of difficulty, which is $13 \mathrm{~km}$ long. It is a very difficult slope, being recommended only to advanced ski and snowboard lovers. The slope is served by the cable car and is not technically arranged.

Poiana Braşov is the most modern and largest ski resort in Romania. It was also included in a top of the best resorts in Southeast Europe. It has the largest ski area in Romania, but also the best conditions for winter sports. The specialized site Trip Advisor chose Poiana Brașov as the best ski place in Romania. "In addition, the ski school here (Ana Ski School), with over 100 certified instructors, was voted 'Best Ski School' in the world by the tour operator Nielsen. Poiana Brașov is perfect for beginners and intermediate skiers."3According to Trip Advisor.

Recently, a new ski resort was opened, namely, Transalpina. The domain has a gondola with 2 sections, 1 quad chair lift and 2 surface lifts. The project developers want to add more elevators in the future to create the largest resort in the southern Carpathian Mountains. The completed project will have 31 ski lifts and 80 kilometers of trails. The resort is built with the help of the Ministry of Sustainable Development and the Romanian Ministry of Tourism and is worth EUR 80 million, supported by EU funding.

The main ski area in Romania, Poiana Braşov, is part of a development project worth 32 million euros, which will include 10 kilometers of new ski slopes served by a gondola and 2 ski lifts. The extension will thus increase the current distance of the ski slopes to more than 30 kilometers with a capacity on the slopes from 4000 to 5000 people. Locally, the municipality is considering the 
expansion of over 30 hectares of new land in the Cheișoara, Râșnov area. Initially allocating around EUR 50,000 to a detailed feasibility study, the mayor of Brasov said that over 2.3 million skiers have used the resort's ski lifts during the last 3 winter seasons.

Poiana Brașov and other ski resorts in Romania have suffered from a deficiency of the snow layer in the last season, and due to high temperatures, the artificial snow installations started operating only after Christmas 2019. The resort in Poiana Brașov hopes to bid for the accommodation of the 2028 Winter Youth Olympic Games, according to Snowhunter.

As a tourist attraction for foreign visitors, Romania stands out with relatively low prices compared to most of Europe. However, the price of subscriptions is not considered really cheap due to the limited and weak infrastructure. It is estimated that the resorts in the Carpathian Mountains attract about 1.2 million skiers annually according to Laurent Vanat in the 2020 Snow \& Mountain Tourism Report. According to the figure no. 3 we can see that the number of winter sports enthusiasts is about 588,000 people, and the 141 cable installations are not enough for a favorable practice of winter sports in Romania.

Figure 3. Graph on the situation of winter destinations in Romania 2020

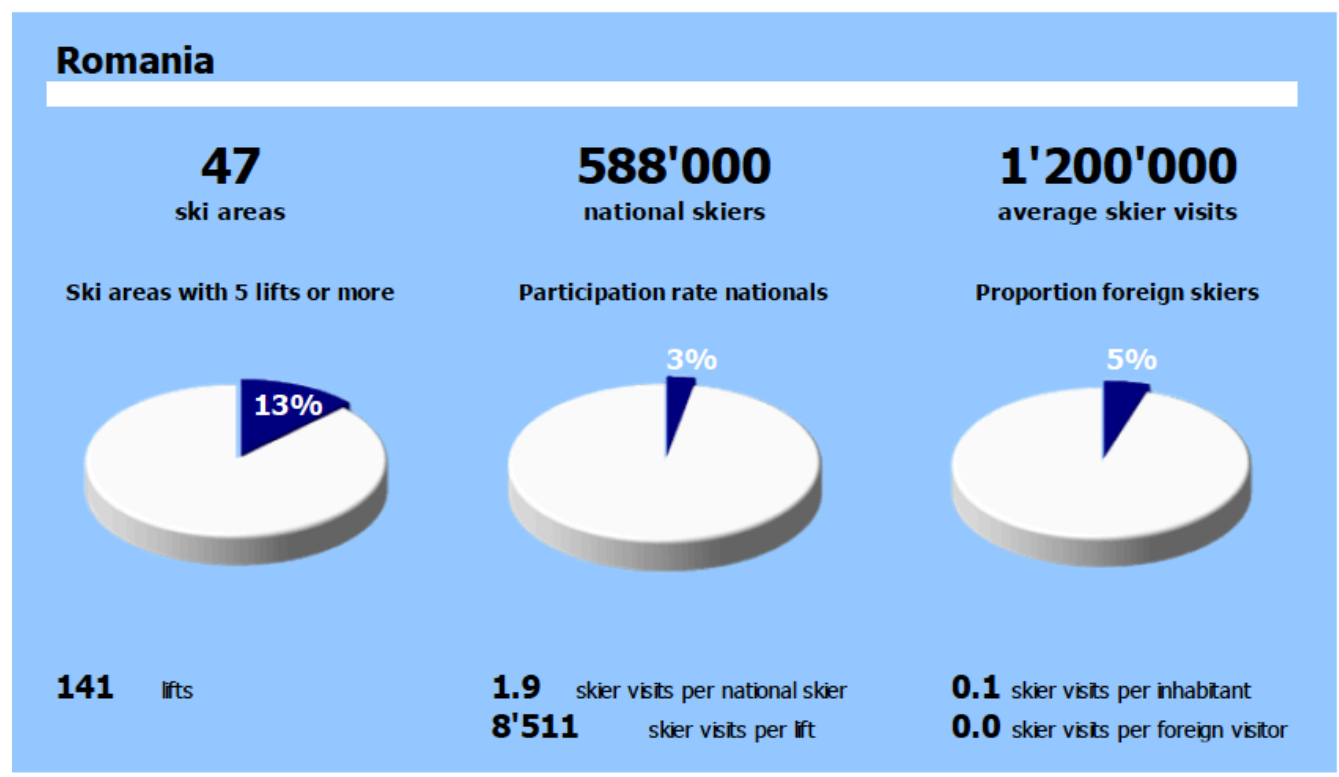

Source: Made by the author based on the information from 2020's Report on Snow \& Mountain Tourism

\subsection{ACCOMODATION CAPACITY}

Divided on both sides of the Carpathians, from the north of the Eastern Carpathians to the south, from the east of the Southern Carpathians to the west, and even from the south of the Western Carpathians to the north, the winter tourist resorts are located on the territory of 20 counties represented in the image below (Figure no. 4), suggestive of the location of the ski slopes in Romania. 
Figure 4. The main winter destination in Romania

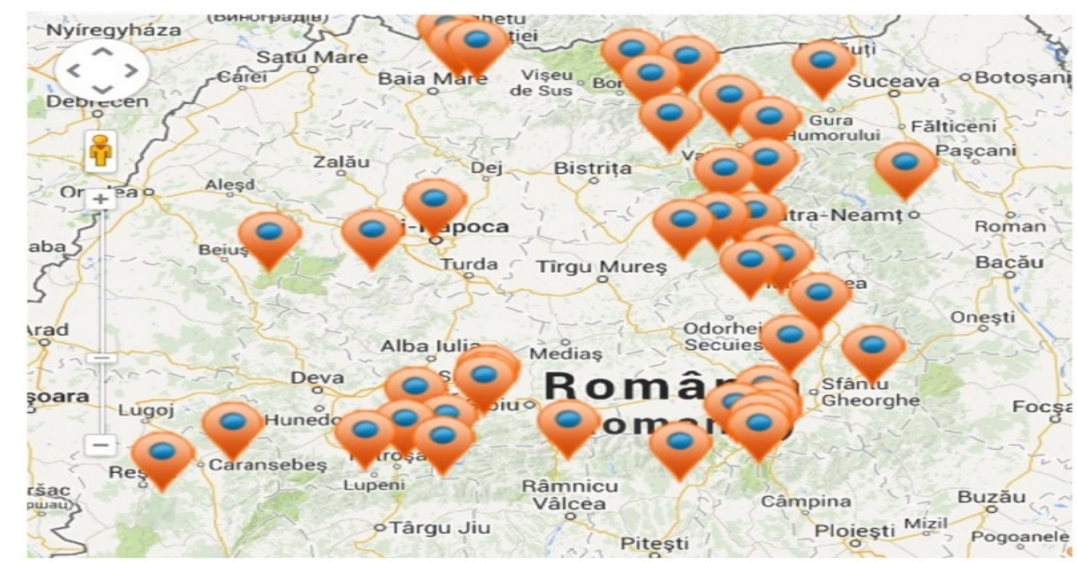

Source: http:/www.i-tour.ro/grid-homepage/harta-interactiva-partii-schi/

According to the National Institute of Statistics, the accommodation capacity in the 20 counties, where mountain tourism is the main income in the field of tourism, are found in 2017: 5469 accommodation units with tourist reception functions, with an increase of $17 \%$ over the year 2016 . An analysis of the accommodation capacity between 2007-2017 can be found in table number 4 regarding the number of tourist reception units in the mountain areas classified by counties.

Table 2. The evolution of accommodation capacity in mountain resorts

\begin{tabular}{|c|c|c|c|c|c|c|c|c|c|c|c|}
\hline Coun & 2007 & 2008 & 2009 & 2010 & 2011 & 2012 & 2013 & 2014 & 2015 & 2016 & 2017 \\
\hline Alba & 46 & 50 & 62 & 67 & 100 & 113 & 121 & 140 & 159 & 159 & 191 \\
\hline Arad & 88 & 89 & 122 & 138 & 139 & 170 & 169 & 160 & 145 & 145 & 140 \\
\hline Bacau & 35 & 34 & 34 & 34 & 47 & 76 & 85 & 84 & 129 & 126 & 147 \\
\hline Bihor & 85 & 83 & 100 & 110 & 128 & 145 & 139 & 149 & 179 & 199 & 216 \\
\hline $\begin{array}{l}\text { Bistrita- } \\
\text { Nasaud } \\
\end{array}$ & 25 & 25 & 25 & 27 & 38 & 49 & 49 & 45 & 44 & 43 & 87 \\
\hline Brasov & 471 & 493 & 482 & 474 & 526 & 646 & 750 & 787 & 886 & 881 & 955 \\
\hline $\begin{array}{l}\text { Caras- } \\
\text { Severin } \\
\end{array}$ & 118 & 118 & 144 & 143 & 149 & 181 & 186 & 188 & 231 & 235 & 241 \\
\hline Cluj & 211 & 206 & 224 & 222 & 195 & 234 & 206 & 184 & 186 & 192 & 283 \\
\hline Covasna & 38 & 37 & 68 & 76 & 91 & 100 & 102 & 105 & 108 & 97 & 104 \\
\hline Gorj & 40 & 40 & 61 & 61 & 69 & 79 & 79 & 87 & 85 & 87 & 102 \\
\hline Harghita & 397 & 415 & 316 & 281 & 229 & 344 & 322 & 321 & 357 & 371 & 409 \\
\hline Hunedoara & 81 & 87 & 93 & 94 & 94 & 96 & 93 & 99 & 108 & 125 & 217 \\
\hline Iasi & 54 & 53 & 74 & 66 & 67 & 78 & 72 & 81 & 99 & 96 & 85 \\
\hline $\begin{array}{l}\text { Maramure } \\
s\end{array}$ & 153 & 183 & 186 & 191 & 172 & 171 & 180 & 168 & 197 & 225 & 277 \\
\hline Mures & 120 & 121 & 107 & 123 & 142 & 214 & 235 & 273 & 282 & 291 & 362 \\
\hline Neamt & 112 & 120 & 181 & 179 & 161 & 177 & 213 & 225 & 234 & 235 & 267 \\
\hline Prahova & 223 & 240 & 230 & 233 & 257 & 262 & 293 & 286 & 314 & 306 & 347 \\
\hline Sibiu & 137 & 152 & 172 & 167 & 109 & 109 & 112 & 119 & 315 & 295 & 338 \\
\hline Suceava & 236 & 233 & 235 & 245 & 271 & 296 & 295 & 296 & 310 & 343 & 441 \\
\hline Valcea & 168 & 165 & 173 & 179 & 211 & 260 & 230 & 233 & 217 & 231 & 260 \\
\hline Total & 2838 & 2944 & 3089 & 3110 & 3195 & 3800 & 3931 & 4030 & 4585 & 4682 & 5469 \\
\hline
\end{tabular}

Source: Made by the author based on the information from: http://statistici.insse.ro

The number of bed accommodation in 2017 was 171211 places, with 12,897 more places than in 2016 and 67,007 more places than in 2007. An analysis of accommodation for the period 2007-2017 for mountain resorts from Romania based on the data from the website of the National Institute of Statistics of Romania are presented in Figure no. 5 on "Evolution of the number of accommodation places". 
Figure 5. Evolution of the number of accommodation places

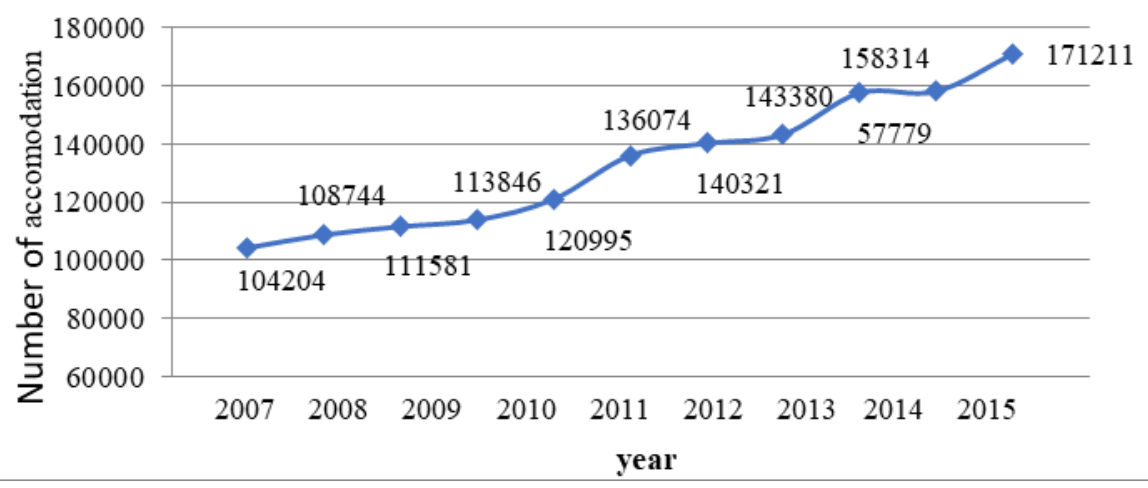

Source: Made by the author based on the information from http://statistici.insse.ro/

\section{METHODS}

In order to carry out the quantitative analysis of the mountain tourism, respectively of the distribution of the ski infrastructure, the SPSS 23.0 software was used and the following variables were included in this study:

- County

- Historical region

- Number of resorts / county

- Total number of practicable kilometers

- Total number of cableway installations

- Accommodation capacity for 2017

To analyze the associations and differences between these indicators, the following statistical methods were applied:

- Pearson parametric correlations to analyze the correlation between the indicators included in the study

- bivariate chi square test to test whether there are statistically significant differences between these indicators by county or historical region

- Student's t test for paired samples to test whether there are statistically significant differences between the averages of these indicators depending on the historical region of the stations in the study

\section{RESULTS AND DISSCUSSIONS}

From Table no. 5 it is observed that there are both correlations of medium intensity and strong intensity, statistically significant, as follows:

- there is a direct correlation of strong intensity (0.931) between Nr. total practicable $\mathrm{km}$ and $\mathrm{T}$ otal number of cableway installations

- there is a direct correlation of medium to strong intensity (0.661) between Nr. Resorts in a county and Total number of cable transport facilities

- there is a direct correlation of average intensity (0.564) between Nr. Resorts in a county and Nr. total practicable $\mathrm{km}$ 
- there is a direct correlation of average intensity (0.535) between Nr. total practicable $\mathrm{km}$ and accommodation capacity

- there is a direct correlation of medium intensity (0.477) between the total number of cable transport installations and the accommodation capacity

Table 3. Pearson correlations coefficients

\begin{tabular}{|c|c|c|c|c|c|}
\hline & & 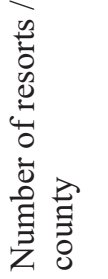 & 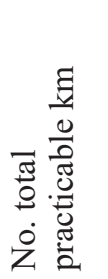 & 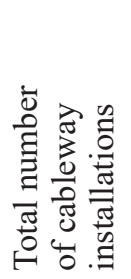 & 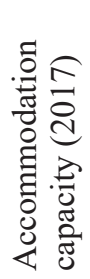 \\
\hline \multirow{3}{*}{ Number of resorts / county } & Pearson Correlation & 1 & $.564^{*}$ & $.661^{* *}$ & .324 \\
\hline & Sig. (2-tailed) & & .012 & .002 & .176 \\
\hline & $\mathrm{N}$ & 19 & 19 & 19 & 19 \\
\hline \multirow{3}{*}{ No. total practicable km } & Pearson Correlation & $.564^{\star}$ & 1 & $.931^{* *}$ & $.535^{\star}$ \\
\hline & Sig. (2-tailed) & .012 & & .000 & .018 \\
\hline & $\mathrm{N}$ & 19 & 19 & 19 & 19 \\
\hline \multirow{3}{*}{$\begin{array}{l}\text { Total number of cableway } \\
\text { installations }\end{array}$} & Pearson Correlation & $.661^{* *}$ & $.931^{\star *}$ & 1 & $.477^{\star}$ \\
\hline & Sig. (2-tailed) & .002 & .000 & & .039 \\
\hline & $\mathrm{N}$ & 19 & 19 & 19 & 19 \\
\hline \multirow{3}{*}{$\begin{array}{l}\text { Accommodation capacity } \\
(2017)\end{array}$} & Pearson Correlation & .324 & $.535^{\star}$ & $.477^{\star}$ & 1 \\
\hline & Sig. (2-tailed) & .176 & .018 & .039 & \\
\hline & $\mathrm{N}$ & 19 & 19 & 19 & 19 \\
\hline
\end{tabular}

*. Correlation is significant at the 0.05 level (2-tailed).

**. Correlation is significant at the 0.01 level (2-tailed).

Source: Made by the author using the SPSS 23.0 program

In the Figure 6., it can be seen the direct correlations between Number of total practicable kilometers and Total number of cableway installations.

Figure 6. Direct correlations

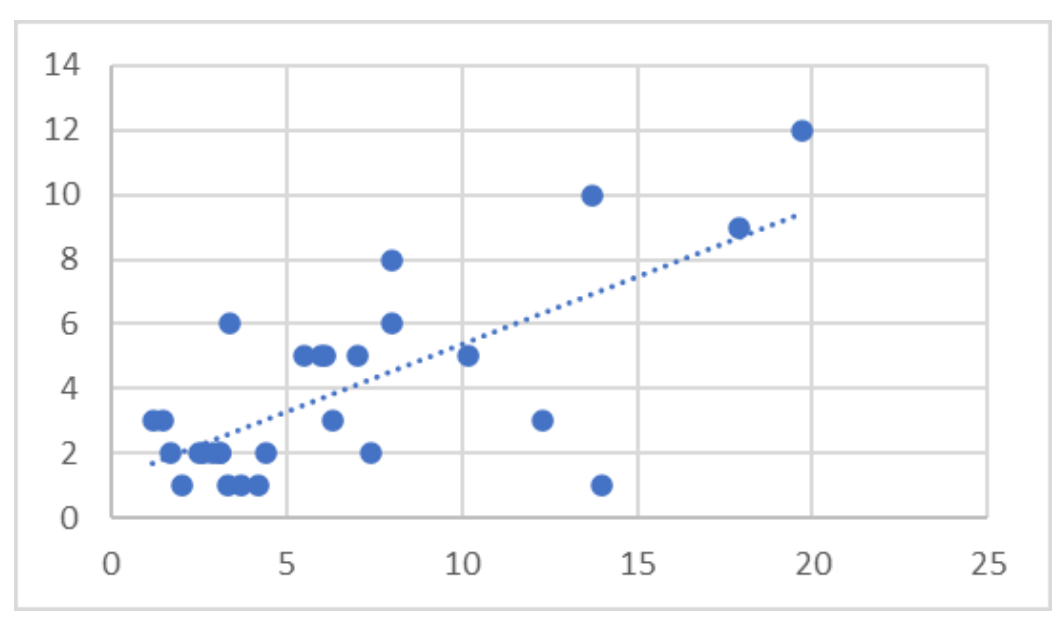

With the help of the bivariate $x^{2}$ test, the null hypothesis was tested $\mathrm{H}_{0}=$ There are no statistically significant differences depending on the county / historical region of the resort regarding the indicators in the study, the results are structurally presented in Table no. 6, where the last column is used to specify if the null hypothesis is accepted or rejected. 
Table 4. Result for Chi square test

$$
X^{2} \text { calculated } \begin{aligned}
& \text { df } \\
& \text { (degrees of } \\
& \text { freedom })
\end{aligned} \quad \text { p-value Decision }
$$

HO = There are no statistically significant differences by county of the resort regarding:

\begin{tabular}{lllll|}
\hline Number of resorts/county & $95.000^{\mathrm{a}}$ & 90 & .339 & $H_{0}$ is accepted \\
\hline No. total practicable km & $342.000^{\mathrm{a}}$ & 324 & .236 & $H_{0}$ is accepted \\
\hline Total number of cableway installations & $190.000^{\mathrm{a}}$ & 180 & .290 & $H_{0}$ is accepted \\
\hline Accommodation capacity (2017) & $342.000^{\mathrm{a}}$ & 324 & .236 & Ho $_{0}$ is accepted \\
\hline
\end{tabular}

$H_{0}=$ There are no statistically significant differences depending on the historical region of the resort regarding:

\begin{tabular}{lllll|}
\hline Number of resorts/county & $33.074^{\mathrm{a}}$ & 30 & .319 & Ho $_{\mathrm{o}}$ accepted \\
\hline No. total practicable km & $114.000^{\mathrm{a}}$ & 108 & .328 & Ho $_{\mathrm{o}}$ is accepted \\
\hline Total number of cableway installations & $76.704^{\mathrm{a}}$ & 60 & $\mathbf{. 0 7 2}$ & $H_{0}$ is rejected \\
\hline Accommodation capacity $(2017)$ & $114.000^{\mathrm{a}}$ & 108 & .328 & Ho $_{0}$ is accepted \\
\hline
\end{tabular}

Source: Made by the author using the SPSS 23.0 program

It is therefore noted that the only hypothesis that can be rejected (for p-value $<0.01$ ) is the one referring to the indicator total number of cableway installations, meaning that there are statistically significant differences between the historical regions of origin of ski mountain resorts according to this indicator.

Applying the Student's t test to compare the means for paired samples, it is observed from the results presented in table no. 5 that there are statistically significant differences depending on the historical region of the resort between the average values of the indicators in the study, for the following indicators:

- No. total practicable km

- Total number of cableway installations

- Accommodation capacity (2017)

Table 5. Results for Student t test

\begin{tabular}{|c|c|c|c|c|c|c|c|c|c|}
\hline & & \multicolumn{5}{|c|}{ Paired Differences } & \multirow{3}{*}{$\mathrm{t}$} & \multirow{3}{*}{$\mathrm{df}$} & \multirow{3}{*}{$\begin{array}{c}\text { Sig. } \\
\text { (2-tailed) }\end{array}$} \\
\hline & & \multirow[t]{2}{*}{ Mean } & \multirow[t]{2}{*}{$\begin{array}{l}\text { Std. } \\
\text { Deviation }\end{array}$} & \multirow[t]{2}{*}{$\begin{array}{l}\text { Std. } \\
\text { Error } \\
\text { Mean }\end{array}$} & \multicolumn{2}{|c|}{$\begin{array}{l}95 \% \text { Confidence } \\
\text { Interval of the } \\
\text { Difference }\end{array}$} & & & \\
\hline & & & & & Lower & Upper & & & \\
\hline $\begin{array}{l}\text { Pair } \\
1\end{array}$ & $\begin{array}{l}\text { Number of resorts / county } \\
\text { - Historical region }\end{array}$ & .211 & 2.699 & .619 & -1.091 & 1.512 & .340 & 18 & .738 \\
\hline $\begin{array}{l}\mathrm{P} \text { a ir } \\
2\end{array}$ & $\begin{array}{l}\text { No. total practicable km - } \\
\text { Historical region }\end{array}$ & 8.5368 & 9.7514 & 2.2371 & 3.8368 & 13.2368 & 3.816 & 15 & .001 \\
\hline $\begin{array}{l}\text { P a i r } \\
3\end{array}$ & $\begin{array}{l}\text { Total number of cableway } \\
\text { installations - Historical } \\
\text { region }\end{array}$ & 5.158 & 6.122 & 1.404 & 2.207 & 8.108 & 3.673 & 18 & .002 \\
\hline $\begin{array}{l}\mathrm{P} \text { a i r } \\
4\end{array}$ & $\begin{array}{l}\text { Accommodation capacity } \\
\text { (2017)- Historical region }\end{array}$ & 278.053 & 195.265 & 44.797 & 183.938 & 372.167 & 6.207 & 18 & .000 \\
\hline
\end{tabular}

Source: Made by the author using the SPSS 23.0 program

Table 6. presents the absolute frequencies and the average values detailed on each indicator and historical region. 
Table 6. Descriptive statistics for indicators grouped by historical regions.

\begin{tabular}{|c|c|c|c|c|c|c|c|}
\hline Indicator & $\begin{array}{l}\text { Historical } \\
\text { region }\end{array}$ & $\begin{array}{l}\text { Absolute } \\
\text { frequency }\end{array}$ & Media & Indicator & $\begin{array}{l}\text { Hist or ical } \\
\text { region }\end{array}$ & $\begin{array}{l}\text { Absolute } \\
\text { frequency }\end{array}$ & Media \\
\hline \multirow{7}{*}{ 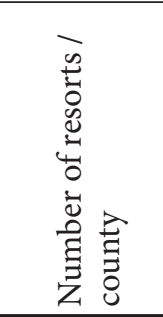 } & Transilvania & 9 & 2.89 & \multirow{7}{*}{ 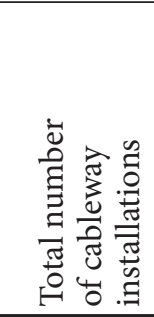 } & Transilvania & 9 & 12.956 \\
\hline & Moldova & 3 & 1.00 & & Moldova & 3 & 1.033 \\
\hline & Oltenia & 3 & 1.67 & & Oltenia & 3 & 7.833 \\
\hline & Maramureș & 1 & 7.00 & & Maramureș & 1 & 20.800 \\
\hline & Crișana & 1 & 3.00 & & Crișana & 1 & 4.200 \\
\hline & Bucovina & 1 & 3.00 & & Bucovina & 1 & 11.200 \\
\hline & Muntenia & 1 & 3.00 & & Muntenia & 1 & 28.800 \\
\hline \multirow{7}{*}{ 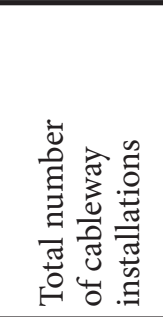 } & Transilvania & 9 & 8.56 & \multirow{7}{*}{ 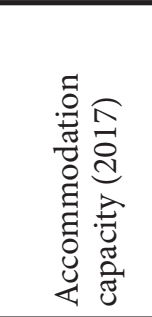 } & Transilvania & 9 & 327.33 \\
\hline & Moldova & 3 & 1.67 & & Moldova & 3 & 166.33 \\
\hline & Oltenia & 3 & 6.33 & & Oltenia & 3 & 201.00 \\
\hline & Maramureș & 1 & 14.00 & & Maramureș & 1 & 277.00 \\
\hline & Crișana & 1 & 5.00 & & Crișana & 1 & 216.00 \\
\hline & Bucovina & 1 & 7.00 & & Bucovina & 1 & 441.00 \\
\hline & Muntenia & 1 & 17.00 & & Muntenia & 9 & 327.33 \\
\hline
\end{tabular}

Source: Made by the author using the SPSS 23.0 program

\section{LIMITATIONS}

In the terms of skiing - as the main component of mountain tourism in the white season - although the area eligible for winter sports has increased significantly in the last 5-10 years, it remains at a value of 300 times lower compared to France or 100 times smaller, compared to Germany, and a proportion of around 50\% of this landscaped area is found in the Bucegi Mountains, Postavaru and Clabucetele Predealului (so a very small perimeter). We add to these findings that most of the slopes are less than $1 \mathrm{~km}$ long, many of them being at low altitudes (where the omata does not last long), and the infrastructure that supports winter sports is outdated or underdeveloped.

The seasonality of tourist activities in the mountain resorts on the "white" component is another delicate issue from the point of view of:

-maintenance of profile equipment in the off-season;

-changing financial resources;

-identifying and dramatizing the human factor with competencies in tourism;

-deformation of working conditions through an activity at high levels during the season and the almost total lack of the "object of work" in the rest of the year;

-social imbalances created by seasonal employment by a large number of non-locals.

For communities from Straja, Poiana Brașov or smal villages as Bucin (Harghita County), winter implies snow. And snow implies life. Since with snow come the swarms that cruel not fair skiers diving down the mountain, but visitors in inns, coffee shops in eateries, clients in basic need stores. No astonish at that point, that for winter sports communities, the rising temperatures that come with climate alter isn't fair an burden or reason to require your coat off (Coca \& Blaga, 2020). They're an existential risk. Since when the winter warms and snow gets to be less and less dependable or basically vanishes, so as well can the swarms. With one ponder anticipating hotter climate seem cruel ski seasons recoil by as much as 50 percent by 2050, increasingly mountain towns synonymous with skiing and winter sports are progressively looking ahead.

Implementing artificial snow systems can be a solution to give winter sports tourists a few extra weeks of skiing this season. A relative example to follow is the ski area in the Toplita area, where with the help of artificial snow the ski season begins in mid-November and ends in late March. It should be noted that artificial snow cannot be compared to natural snow, because of this, many 
Romanian tourists prefer to travel to countries such as Austria, Switzerland, France for winter holidays.

Another important aspect to consider within the development limits of the mountain resorts is the poor condition of the road roads and the non-existence of the speed roads between the key cities of Romania (Gabor et al, 2012; Gabor \& Oltean, 2017). Currently, there are $912 \mathrm{~km}$ of highway and $1423 \mathrm{~km}$ in projects to be completed. Thus, the difficult difficulty of traveling in Romania makes a road distance of approximately $100 \mathrm{~km}$ to be achieved in more than 3-4 hours.

Like all the sectors of tourism, winter sports tourism has suffered due to restrictions imposed by the authorities during the COVID 19 pandemic. At the level of Romania, the mountain resorts were and are open to tourists at the moment, with the imposition of some imposed measures. Thus, the capacity of restaurants, cafes and bars operates at $30 \%$ of capacity, and cable transport installations especially those equipped with chairlifts and cabins at $50 \%$ of capacity. In addition to these restrictions, the fear of people to travel and enjoy winter sports during a pandemic may have major influences in reducing the number of tourists on ski slopes and winter resorts in Romania. According to Baba et all (2020) while the situation on the Romanian tourism market is bleak, a given the recent growing desires of tourists there is a chance of a systematic return. 


\section{CONCLUSIONS}

The added value of tourism in Romania is offered by the so-called "practice of a total tourism" expressed by the diversity of natural and anthropic resources that the tourist territory of Romania can enjoy.

The primary portion of the show paper bargains with a few hypothetical issues in two major steps - specifically, what we get it beneath the term "resource" and what it implies within the setting of postmodern tourism. Based on the surveyed writing, it can be stated that conventional assets are not continuously vital within the case of unused, modern shapes of tourism. The speculation joins the two fundamental hypothetical viewpoints on understanding asset. The relativization of assets may be a postmodern wonder, and this burst, de-localization, or "resource-free" viewpoint can be followed within the Romanian tourism as well; and, what is more, it can be communicated in numbers.

Following this quantitative analysis of the indicators that characterize the winter tourist activity, especially in the mountainous areas of Romania, we can conclude that there are significant differences between the main mountainous regions of the country regarding the total number of cable transport facilities, according to the $\chi^{2}$ bivariate test results. There are also statistically significant differences between mountain regions in terms of the total number of practicable kilometers, the total number of cable transport facilities and accommodation capacity, according to the Student's $t$ test applied. There are also statistically significant correlations between most indicators in the study. All these results, obtained with statistical methodology, support and highlight the significant differences between the Romanian mountain resorts for winter activities.

Mountain tourism and especially the consequences of mountain tourism by practicing winter sports can be found mostly in the Carpathians, in the counties and cities/mountain towns in Romania. The development of winter tourist resorts aims in particular at developing the infrastructure and the material base. Through the projects in force, the resorts are assuming an increase in the number of skiable kilometers and cable transport facilities.

Poiana Brașov is one of the oldest destinations suitable for winter sports and it is prefered by most tourists, thus creating multiple opportunities for the development of this tourist area, the spaces and the number of accommodation places.

There is an annual increase in the number of resorts and winter destinations, and with this increase, there comes a need for increasing the supply and quality of tourism in mountain areas for winter sports.

Future research will be based on the preferences and motivations of Romanian consumers in the practice of winter sports (Bacoș \& Gabor, 2020) in Romania comparatively with a competitive country, Austria and a post-consumption evaluation of these tourist packages for winter tourism in Romania. Also, for the relevance of the next studies, we will take in considerations to include development of a Romanian destination innovativeness model by grouping the elements of interest into and using the structural equation model methodology: political and legal environment; sociocultural environment; natural environment and technological environment. This paper fills a gap in the literature, both of theoretical and practical pint of view, being the first that use the statistical analysis for winter destinations in Romania. 


\section{REFERENCES}

Baba, C.A., Stăncioiu, A.F., Gabor, M.R., Alexe, F.A., Oltean, F.D., \& Dinu, A.C. (2020). Considerations regarding the effects of COVID-19 on the tourism market. Theoretical and Applied Economics, 22, 271-284.

Bacoș, I.B., \& Gabor, M.R. (2020). Consumers' Preferences of Winter Tourist Packages in Romania: A Quantitative Case Study. Annals of "Dunărea de Jos" University of Galati Fascicle I. Economics and Applied Informatics, 3, 157-164. https://doi.org/10.35219/eai15840409150.

Bacoș, I. B. (2018). Studiu comparativ privind sporturile de iarnă Austria-România (Comparative study of the winter sports Austria - Romania) [bachelor thesis]: "Petru Maior" University of Târgu Mureș, Romania.

Cameron W., Eric E. Heather H., David M., Justin S., Matthew R., ..., \& Jeremy M. (2017). Projected climate change impacts on skiing and snowmobiling: A case study of the United States. Global Environmental Change, vol. 45.

Cianga, N. (2002). Romania - Geografia turismului (Romania - Tourism geography). Cluj: Presa Universitara Clujeană, p. 185.

Coca,A., \& Blaga, P. (2020). Gaps and preliminary perspectives concerninginnovation infrastructure in the Carpathian Countries. Acta Marisiensis. Seria Oeconomica, 1, 41-60.

Dwyer, L., \& Kim, C. (2003). Destination Competitiveness: Determinants and Indicators. Current Issues in Tourism, 6, 369-414.

Rouss, E., Alfare, L. (2013). Sustainable tourism as driving force for cultural heritage sites development. Planning. Managing and Monitoring Cultural Heritage Sites in South East Europe. National Research Council of Italy, pp. 49-65.

Gabor, M.R, Conțiu, L.C., \& Oltean, F.D. (2012). A comparative analysis regarding European tourism competitiveness: emerging versus developed markets. Procedia Economics and Finance, . 3, 361-366. https://doi.org/10.1016/S2212-5671(12)00165-7

Gabor, M.R., \& Oltean, F.D. (2017). What macroeconomic index differentiate or similar the European tourism competitiviness? A multimethod analysis. North Economic Review, 1, 201-207.

Global Water Partnership (2018). The Enabling Environment 2018. Retrieved from https://www.gwp.org/en/learn/iwrm-toolbox/The-Enabling-Environment/.

I-Tour (2018). Harta interactiva partii schi Romania (Interactive map of Romanian ski slopes) Retrieved from http://www.i-tour.ro/grid-homepage/harta-interactiva-partii-schi/

Lobo, R. F. (2003). Introduction to the structural chemistry of zeolites. In: S. Auerbach, K. Carrado, \& P. Dutta (Eds.), Handbook of zeolite science and technology, pp. 65-89.

National Institute of Statistics (2018). Retrieved from http://statistici.insse.ro/shop/index.jsp?page=tempo3\&lang=ro\&ind=TUR102D, accessed on 20 March 2018.

Nagy, B. (2019). Tourism with No Resources? Acta Universitatis Sapientiae. Economics and Business, vol 7, pp. 5 -22, DOI: 10.1515/auseb-2019-0001

Neacșu, M., Neacșu, N., Baron, P, Glavan, V (2011). Geografia si economia turismului (Geography and economy of tourism). Bucharest: Pro Universitaria, pp.155-176.

Oliver K. (2020) Ski resorts Romania. Retrieved from https://www.skiresort.info/ski-resorts/romania/

Price, M.F., Jansky, L., Iatsenia, A. (2004). Key Issues for Mountain Areas. New York: United Nations University Press.

Ringbeck, J., Gross, S., Chiesa, T., Blanke, J. (2008). Improving Travel \& Tourism Competitiveness. In book: Trends and Issues in Global Tourism, pp. $97-108$, DOI: https://doi.org/10.1007/978-3-540-77798-4_8

Ritchie, J.R.B., Crouch, G.I. (2003) The Competitive Destination: a Sustainable Tourism 
Perspective, CABI.

Ski-Lifts (2020). 4 facts about ski tourism on World Tourism Day. Retrieved from https://www.ski-lifts.com/guides/transfers/4-facts-about-ski-tourism-for-world-tourismday/, accessed on December 2020.

Ski \& Snowboard (2020). Ski slopes. Bâlea. Retrieved from http://ski-si-snowboard.ro/partii/balea-1340

STATISTA. (2020). Sales of skis into retail and rental in the United Kingdom (UK) from 2001/02 to 2016/17, Retrieved from

https://www.statista.com/statistics/291402/retail-rental-unit-sales-of-skis-in-great-britain/, accessed on December 2020.

STATISTA (2020). Number of people who ski in Europe as of 2020, by country, Retrieved from https://www.statista.com/statistics/801008/europe-number-of-people-skiing-by-country/, accessed on December 2020.

STATISTA (2020). Statista dossier about skiing in Europe, Retrieved from https://www.statista.com/study/41124/skiing-in-europe-statista-dossier/, accessed on December 2020.

Suciu, S. (2016). Topul celor mai bune staţiuni şi pârtii de schi din România. Cât ne costă acest sport de iarnă (Top of the best resorts and ski slopes in Romania. How much does this winter sport cost us). Adevărul 5 December 2016. Retrieved from http://adevarul. ro/locale/brasov/topul-celor-mai-bune-statiuni-sipartii-schi-romania-costa-sport-iarna1 5843ce3a5ab6550cb8194edb/index.html

The Romanian Ministry of Economy, Energy and Business Environment (2017). Turism - pârtii de schi omologate (Tourism-Approved ski parts). Retrieved from http://turism.gov.ro/web/autorizare-turism/ accessed on 15 March 2018

Travel Minit (2020). Pârtii de schi, stațiuni de schi România (Ski slopes, ski resorts in Romania). Retrieved from https://travelminit.ro/ro/partii-statiuni-schi-romania, accessed on 10 March 2018.

Trip Advisor (2020). Explore Poiana Brasov. Retrieved from https://www.tripadvisor.com/ Tourism-g616229-Poiana_Brasov_Brasov_County_Central_Romania_TransylvaniaVacations.html

Valcea Turistica (2018). Ski Resort Transalpina. Retrieved from http://www.valceaturistica.ro/destinatii/ski-resort-transalpina-voineasa/ accessed on 10 March 2018

Vanat, L. (2020). 2020 International Report on Snow \& Mountain Tourism Overview of the key industry figures for ski resorts, Geneva. Retrieved from www.vanat.ch/tarif-WR-data-2020.pdf

Vanat, L. (2020). The 2020 International Report on Mountain \& Snow Tourism. Retrieved from https://www.the-ski-guru.com/2020/04/22/2020-international-report-mountain-snowtourism-published/, pp 128-129.

Wood, R. (2010). List of Winter Olympic Sports. Topend Sports Website, Retrieved from https://www.topendsports.com/events/winter/sports/index.htm, accessed on 15 February 2018

World Tourism Organization \& Romanian Government. Master Plan for the Development of National Tourism 2007-2026. Retrieved from https://www.infotravelromania.ro/master plan turism/master_plan.pdf, accessed on 08 February 2021. 